\title{
A refined TALDICE-1a age scale from 55 to 112 ka before present for the Talos Dome ice core based on high-resolution methane measurements
}

\author{
S. Schüpbach ${ }^{1,2}$, U. Federer ${ }^{1,2}$, M. Bigler ${ }^{1,2}$, H. Fischer ${ }^{1,2}$, and T. F. Stocker ${ }^{1,2}$ \\ ${ }^{1}$ Climate and Environmental Physics, Physics Institute, University of Bern, Sidlerstrasse 5, 3012 Bern, Switzerland \\ ${ }^{2}$ Oeschger Centre for Climate Change Research, University of Bern, Bern, Switzerland
}

Received: 6 April 2011 - Published in Clim. Past Discuss.: 8 April 2011

Revised: 28 July 2011 - Accepted: 24 August 2011 - Published: 26 September 2011

\begin{abstract}
A precise synchronization of different climate records is indispensable for a correct dynamical interpretation of paleoclimatic data. A chronology for the TALDICE ice core from the Ross Sea sector of East Antarctica has recently been presented based on methane synchronization with Greenland and the EDC ice cores and $\delta^{18} \mathrm{O}_{\text {ice }}$ synchronization with EDC in the bottom part (TALDICE-1). Using new high-resolution methane data obtained with a continuous flow analysis technique, we present a refined age scale for the age interval from 55-112 thousand years (ka) before present, where TALDICE is synchronized with EDC. New and more precise tie points reduce the uncertainties of the age scale from up to $1900 \mathrm{yr}$ in TALDICE-1 to below $1100 \mathrm{yr}$ over most of the refined interval and shift the Talos Dome dating to significantly younger ages during the onset of Marine Isotope Stage 3. Thus, discussions of climate dynamics at sub-millennial time scales are now possible back to $110 \mathrm{ka}$, in particular during the inception of the last ice age. Calcium data of EDC and TALDICE are compared to show the impact of the refinement to the synchronization of the two ice cores not only for the gas but also for the ice age scale.
\end{abstract}

\section{Introduction}

For a good understanding of the mechanisms at work in the climate system it is indispensable to know the chronology and phase relationships of climate events in the past. Pre-

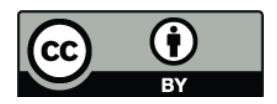

Correspondence to: S. Schüpbach (schuepbach@climate.unibe.ch) cise dating of climate archives such as ice cores is therefore necessary to optimally utilize the information stored in such archives. Ice cores contain various strains of information on climate and environmental changes in the past. These comprise the water isotopic signature of the ice matrix, dissolved and particulate aerosol tracers as well as the gas composition of the atmosphere all in one climate archive. Accordingly, synthesizing these strains of ice core information circumvents crucial cross-dating issues that affect the comparison of independent climate archives. For the comparison of different ice cores, absolute dating of each core is not necessary, it is sufficient to synchronize the records properly by the use of a global tracer. Air trapped in polar ice cores has the unique property of containing global tracers of the atmosphere, which show the same variations over time at drilling sites on both hemispheres. Thus, it is possible to build relative age scales of different ice cores by synchronizing the respective methane $\left(\mathrm{CH}_{4}\right)$ records (Blunier and Brook, 2001; Blunier et al., 1998, 2007; Chappellaz et al., 1997; EPICA, 2006). Methane is particularly well suited for such a synchronization because abrupt concentration changes have been observed over large periods back to 800 thousand years before present (ka BP, i.e. before 1950 AD), not only at glacial-interglacial transitions but also during glacial times, especially during Dansgaard-Oeschger (DO) events (Brook et al., 2000; Chappellaz et al., 1997; Huber et al., 2006; Loulergue et al., 2008; Spahni et al., 2005). These abrupt $\mathrm{CH}_{4}$ concentration changes are global time markers which have been well archived in all polar ice cores since the interhemispheric mixing time today is about ten times shorter than the atmospheric lifetime of $\mathrm{CH}_{4}$ and

Published by Copernicus Publications on behalf of the European Geosciences Union. 
was still much shorter during glacial times (Fischer et al., 2008; Lelieveld et al., 1998).

The synchronization of ice cores is limited by the mixing of the air in the firn before bubble close-off which causes different age distributions of the enclosed gas depending on accumulation and temperature at the drilling site. This age distribution as well as the firnification process can be modelled (Goujon et al., 2003; Schwander et al., 1993; Spahni et al., 2003) within its model uncertainties. It has been shown that additional uncertainties of methane tie points of up to $200 \mathrm{yr}$ can be caused by different gas enclosure characteristics at different drilling sites (Köhler et al., 2011). Even larger errors may arise for very low accumulation rate sites (such as Vostok, Dome Fuji or Dome C), where firnification models seem to be in contradiction with $\delta^{15} \mathrm{~N}_{2}$ measurements (Landais et al., 2006). Another important limitation usually is the limited resolution of the methane records. Records with higher resolution reflect fast concentration changes in more detail and therefore, tie points can be defined more precisely.

The first official chronology (TALDICE-1) of the deep ice core TALDICE (TALos Dome Ice CorE) at Talos Dome in the Ross Sea sector of East Antarctica $\left(72^{\circ} 47^{\prime} \mathrm{S}, 159^{\circ} 11^{\prime} \mathrm{E}\right)$, based on an inverse model (Lemieux-Dudon et al., 2010) and methane synchronization with Greenland ice cores (Blunier et al., 2007) (0-50 ka BP) and the EPICA Dome C (EDC) ice core (Loulergue et al., 2008; Spahni et al., 2005) (50$140 \mathrm{kaBP}$ ) as well as $\delta^{18} \mathrm{O}_{\text {ice }}$ synchronization with EDC for ages older than $140 \mathrm{ka}$, has recently been published by $\mathrm{Bu}-$ iron et al. (2011). The well-resolved (mean resolution of $87 \mathrm{yr}$ ) TALDICE methane record was synchronized with the Greenland record back to $50 \mathrm{kaBP}$. The relative age uncertainty of TALDICE-1 remains lower than $600 \mathrm{yr}$ in this period (except for the Last Glacial Maximum where abrupt methane variations are missing). However, for the time period from 50-140 ka BP where the methane synchronization was made with the EDC ice core, the age uncertainty increases to $2 \mathrm{ka}$, mainly due to the coarse resolution (mean resolution of $620 \mathrm{yr}$ ) of the TALDICE methane record.

The purpose of this paper is to apply a new continuous measurement technique for methane (Schüpbach et al., 2009) and to produce a high-resolution $\mathrm{CH}_{4}$ record for the early part of the last ice age. In the new record we define 12 new age tie points which result from the high-resolution record. With these additional constraints, we are able to present a refined age scale (TALDICE-1a) for the time period from 55$112 \mathrm{ka}$ BP based on the TALDICE- 1 age scale. The impact of the refinement of the age scale to the synchronization of TALDICE and EDC ice cores is shown by a comparison of Calcium $\left(\mathrm{Ca}^{2+}\right)$ records of the two cores in a selected interval. This provides an independent means of verifying the quality of the revised age scale TALDICE-1a.

The paper is organised as follows: In Sect. 2 we describe the new high-resolution $\mathrm{CH}_{4}$ data and the construction of the revised age scale. Section 3 presents a discussion of the im- plications of the new time scale, in particular on ice-based records, and conclusions are given in Sect. 4.

\section{Experimental methods and age scale construction}

Methane measurements on TALDICE were performed with a new on-line melting technique using a Continuous Flow Analysis (CFA) system (Schüpbach et al., 2009) in the depth interval from $1187 \mathrm{~m}$ to $1488 \mathrm{~m}$. These measurements cover the section where TALDICE was synchronized with the EDC ice core (1228 m to $1428 \mathrm{~m}$, Buiron et al., 2011) by the use of discrete methane measurements using a traditional meltrefreeze extraction method (Chappellaz et al., 1997; Spahni et al., 2005). The new on-line record yields a mean depth resolution of $26 \mathrm{~cm}$ in the depth interval examined in this study (547 data points from 1239 to $1380 \mathrm{~m}$ ), compared to a mean depth resolution of $1.52 \mathrm{~m}$ of the methane record used for the synchronization with the EDC record by Buiron et al. (2011). Even though the precision of the on-line measurements is lower ( $1 \sigma$ of $15-20 \mathrm{ppbv})$ than the one of the discrete measurements ( $1 \sigma$ of $10 \mathrm{ppbv})$ and absolute calibration is an issue, the new dataset is very well suited for a refined synchronization of the TALDICE and the EDC methane records. This is due to the considerably higher depth resolution of the new dataset, and because the magnitude of atmospheric $\mathrm{CH}_{4}$ variability (in the range of $350 \mathrm{ppb}$ to $750 \mathrm{ppb}$ during the last glacial period) is much larger than the uncertainty of the measurement. This allows for the definition of more tie points with better precision. Gaps in our high-resolution $\mathrm{CH}_{4}$ record (see Fig. 3) longer than $1 \mathrm{~m}$ were caused either by several distinct ash layers in the ice core that were not measured with CFA ( $3 \mathrm{~m}$ at $86.5-88.5 \mathrm{ka}, 2 \mathrm{~m}$ at $107-109 \mathrm{ka}$ and $4 \mathrm{~m}$ at $111.5-115 \mathrm{ka} \mathrm{BP})$ or maintenance of the GC system ( $12 \mathrm{~m}$ at 61-64 ka BP) while the CFA measurements were continued.

A methane record covering the Antarctic Cold Reversal (ACR) was measured with the same method on TALDICE and presented in Schüpbach et al. (2009). This record features a nominal resolution of 3-10 yr. However, no large concentration variations of methane in the air trapped in ice are possible within such short time periods due to the slow bubble close-off process (Schwander et al., 1993). Therefore, the data were filtered by a binomial 5-point filter to smooth out artificial variations induced by the measurement uncertainty without corrupting the signal during fast concentration increases or decreases. Since these high-frequency variations are a measurement artefact, the filter is not applied on a constant time window but always over five consecutive data points, i.e. on a constant depth interval. This same filter was applied for all the high-resolution data presented in this work featuring similar depth resolution but much lower resolution in time (mean temporal resolution of $103 \mathrm{yr}$ ) than the data covering the ACR. In doing so, measurement artefacts were filtered reliably, but atmospheric $\mathrm{CH}_{4}$ variations were potentially smoothed since the mean temporal resolution of 


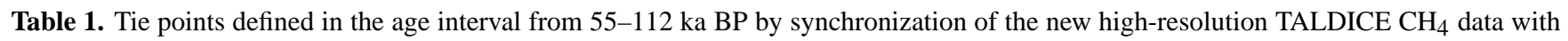
the $\mathrm{EDC} \mathrm{CH}_{4}$ record on the EDC3 age scale. The indicated uncertainty is from visual matching of TALDICE and EDC only. Additionally indicated are the corresponding depths of the EDML ice core for all the new tie points and the sample resolutions of the EDC and TALDICE $\mathrm{CH}_{4}$ records, respectively, for each tie point.

\begin{tabular}{rrrrrrl}
\hline $\begin{array}{r}\text { EDC } \\
\text { depth }\end{array}$ & $\begin{array}{r}\text { TALDICE } \\
\text { depth }\end{array}$ & $\begin{array}{r}\text { EDML } \\
\text { depth }\end{array}$ & $\begin{array}{r}\text { Gas age } \\
\text { EDC3 }\end{array}$ & $\begin{array}{r}\text { Resolution } \\
\text { EDC/TALDICE }\end{array}$ & Uncertainty & Comments \\
\hline$(\mathrm{m})$ & $(\mathrm{m})$ & $(\mathrm{m})$ & $(\mathrm{yr} \mathrm{BP})$ & $(\mathrm{yr})$ & $(\mathrm{yr})$ & \\
\hline 44.50 & 1239.00 & & 55150 & & 200 & $*$ \\
969.65 & 1255.50 & 1663.50 & 57400 & $220 / 20$ & 220 & \\
980.39 & 1260.50 & 1681.03 & 58280 & $150 / 20$ & 160 & onset DO 17 \\
984.52 & 1262.67 & 1686.98 & 58610 & $180 / 50$ & 190 & precursor DO 17 \\
1039.51 & 1287.75 & 1764.10 & 64020 & $240 / 30$ & 250 & onset DO 18 \\
1105.55 & 1306.25 & 1862.50 & 71100 & $200 / 70$ & 210 & onset DO 19 \\
1141.27 & 1314.57 & 1914.50 & 74630 & $200 / 55$ & 200 & onset DO 20 \\
1196.27 & 1326.14 & 1978.10 & 79875 & $180 / 55$ & 190 & \\
1234.77 & 1332.75 & 2019.80 & 83070 & $170 / 65$ & 190 & peak DO 21 \\
& 1334 & 2425.20 & 83650 & & & precursor DO 21 \\
1248.52 & 1335.25 & 2031.20 & 84230 & $190 / 75$ & 200 & \\
1302.70 & 1345.00 & & 89500 & & 500 & $*$ \\
1369.3 & 1356 & & 96000 & & 500 & $*$ \\
1427.27 & 1367.1 & 2196 & 101690 & $220 / 60$ & 230 & onset DO 23 \\
1432.77 & 1368.4 & 2199.32 & 102240 & $230 / 100$ & 250 & \\
1471.27 & 1374.75 & 2228.99 & 106550 & $230 / 80$ & 250 & onset DO 24 \\
1515.4 & 1380.00 & & 112000 & & 1000 & $*$ \\
\hline
\end{tabular}

* Tie point adopted from Buiron et al. (2011).

the $\mathrm{CFA}-\mathrm{CH}_{4}$ record presented in this study is in the order of magnitude of the bubble close-off time. However, the potential smoothing of atmospheric variations does not have implications on the result of the synchronization of the $\mathrm{CH}_{4}$ records of TALDICE and EDC as long as tie points can still be clearly identified.

The filtered high-resolution methane record was then synchronized to the EDC methane data by visually matching fast transitions in the two methane records. The tie points were chosen at mid-slope of the transitions at the onset of Dansgaard-Oeschger (DO) events or at the maxima of very short methane peaks (e.g. the very pronounced event at $58600 \mathrm{ka} \mathrm{BP}$ preceding DO 17 in Fig. 1). Due to the high resolution of the new Talos Dome methane record the uncertainty of the visual matching remains always lower than $300 \mathrm{yr}$ (compared to 400-1500 yr in Buiron et al., 2011) in the discussed depth interval. This uncertainty depends only on the resolution of both records and is calculated as the square root of the sum of squares of the EDC and TALDICE time resolution at the respective tie point (see Table 1). Not included in this uncertainty is the additional synchronization error caused by different bubble close-off characteristics of Dome $\mathrm{C}$ and Talos Dome. This additional error is lower than the $200 \mathrm{yr}$ calculated by Köhler et al. (2011). This is because Köhler et al. (2011) compare the EDC and NGRIP ice cores where bubble close-off characteristics are very different. The close-off characteristics of TALDICE is more similar to those of EDC, resulting in smaller synchronization uncertainties. In order to obtain the uncertainty of the absolute gas age of each tie point, the uncertainties caused by visual matching have to be added to the inherent uncertainty of the EDC3 age scale of 1-4 ka BP in the interval discussed in this work (Parrenin et al., 2007).

As the TALDICE-1 age scale both for ice and gas is based on gas tie points only (for ages younger than $141 \mathrm{ka} \mathrm{BP}$ ), shifting the gas tie points has direct implications on the age of the ice. The age difference between the gas and the ice at the same depth $(\Delta$ age $)$ is largely dependent on the accumulation rate. Since changes in the accumulation rate in the refined age scale caused by shifting tie points do not exceed $16 \%$, i.e. stay well within the uncertainty of the accumulation rate given by Buiron et al. (2011) ( $\pm 20 \%)$, we applied the modeled $\triangle$ age of TALDICE- 1 to the refined gas age scale in order to derive the age of the ice at the corresponding depth.

Soluble calcium $\left(\mathrm{Ca}^{2+}\right)$, a tracer for mineral dust input, was analyzed on the entire TALDICE with a well-established CFA system used for the determination of aerosol constituents in ice cores (Kaufmann et al., 2008). In the depth interval from $1220 \mathrm{~m}$ to $1323 \mathrm{~m}$ discussed here, a continuous high-resolution $\mathrm{Ca}^{2+}$ record was obtained except for a gap of four meters (1276-1280 m), where $\mathrm{Ca}^{2+}$ data were not available. The nominal depth resolution of the continuous $\mathrm{Ca}^{2+}$ 


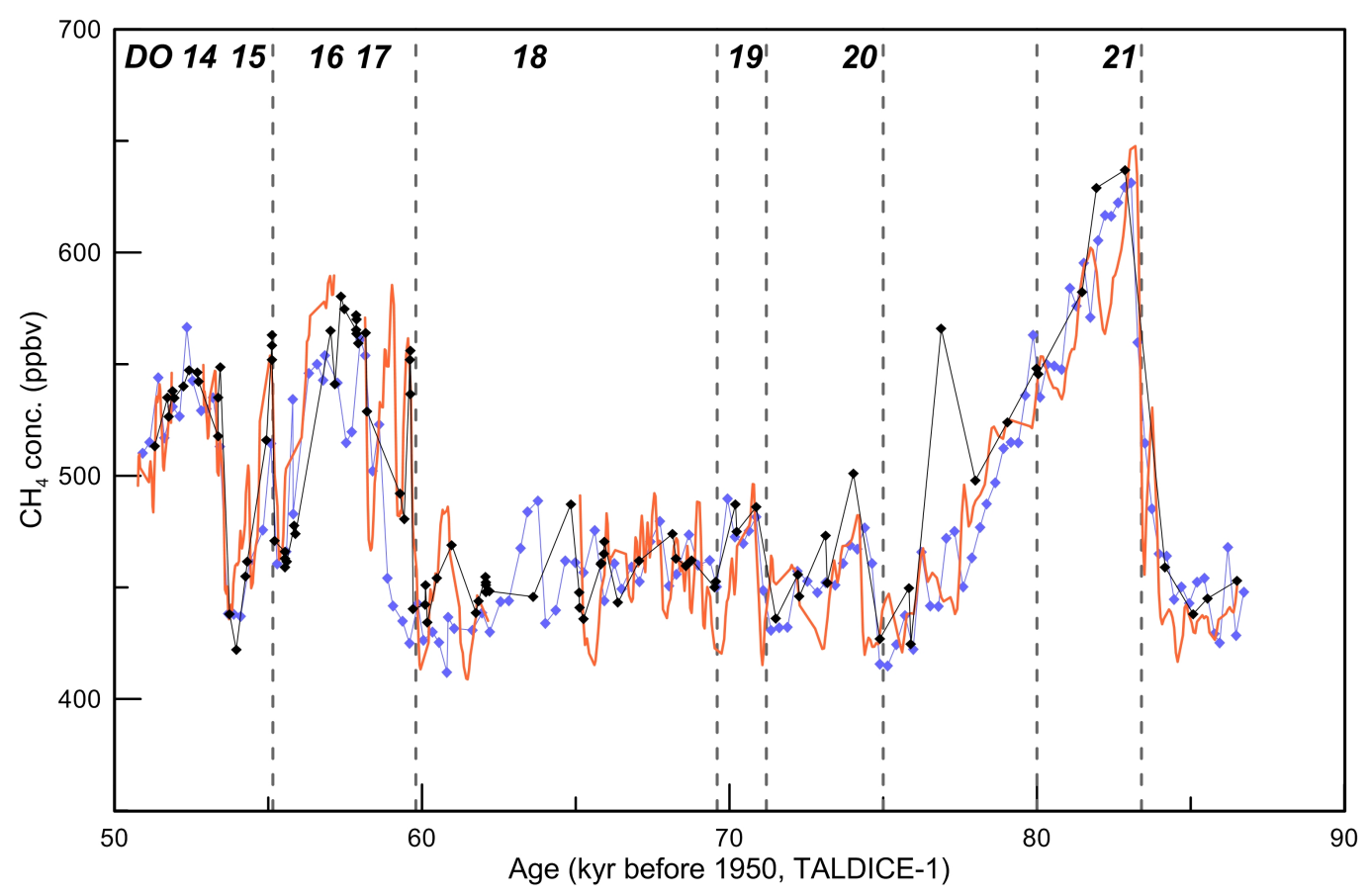

Fig. 1. The EDC $\mathrm{CH}_{4}$ record (blue diamonds) on the EDC3 age scale is compared to the TALDICE $\mathrm{CH}_{4}$ record (black diamonds, Buiron et al., 2011) on the TALDICE-1 age scale. The new high-resolution $\mathrm{CH}_{4}$ record (orange line) is also shown on the TALDICE-1 age scale. Dashed lines indicate the tie points of the TALDICE-1 age scale used by Buiron et al. (2011). Bold italic numbers indicate DansgaardOeschger (DO) events.

record is typically $1 \mathrm{~cm}$ (Bigler et al., 2006), for the purpose of this study the high-resolution $\mathrm{Ca}^{2+}$ record is downsampled to a depth resolution of $50 \mathrm{~cm}$ to compare with the EDC $\mathrm{Ca}^{2+}$ record. The mean measurement error of the $\mathrm{Ca}^{2+}$ concentration record is estimated to be less than $10 \%$ (Röthlisberger et al., 2000).

\section{Results and discussion}

Figure 1 shows the Dome $\mathrm{C}$ methane record in the time interval from 50-86 ka BP on the EDC3 age scale (Loulergue et al., 2007; Loulergue et al., 2008) along with the discrete methane data on the TALDICE-1 age scale (Buiron et al., 2011). With the new high-resolution methane data overlaid (orange line), discrepancies between the two age scales appear which could not be unambiguously detected with the discrete measurements only. For example, at the onset of DO 17 preceded by a distinct precursor event the TALDICE1 gas age is biased $1000 \mathrm{yr}$ towards older ages. Replacing the tie point at $59800 \mathrm{yr}$ BP with a tie point at the peak of the precursor event (58600 yr BP on the EDC3 age scale) and thus shifting TALDICE-1 approx. $1000 \mathrm{yr}$ towards younger ages while keeping the tie point at $71200 \mathrm{yr}$ BP fixed (onset of DO 19) stretches the data in a way that an additional tie point at the onset of DO 18 becomes apparent (see Fig. 2).
The same procedure has been applied for the entire period from 55-112 ka BP shown in Fig. 3. By matching all the fast transitions at the onsets of DO 16-24, precursor events or other distinct signals in the two methane records, 12 new tie points were defined in the age interval from 55-112 ka BP, four of the tie points proposed by Buiron et al. (2011) were adopted unchanged (see Table 1 and Fig. 3). Correlation coefficients between EDC $\mathrm{CH}_{4}$ and $\mathrm{CFA}-\mathrm{CH}_{4}$ on the TALDICE- 1 age scale and on the revised TALDICE1a age scale have been calculated by linearly interpolating the $\mathrm{CFA}-\mathrm{CH}_{4}$ record to obtain concentration values in the high-resolution record at exactly the same age as the EDC data points. For the 208 data points in the investigated interval correlation on the TALDICE-1 age scale is $r^{2}=0.68$ compared to $r^{2}=0.81$ on the revised age scale. The TALDICE $\mathrm{CH}_{4}$ data on the whole interval of the refined age scale is shown in Fig. 3 along with the $\mathrm{EDC} \mathrm{CH}_{4}$ data. This new TALDICE-1a age scale is not meant to replace the TALDICE-1 age scale, it is rather a refinement of this age scale in the above mentioned time interval. Figure 4a shows how much the gas age scale has been changed by the construction of the new age scale with respect to the original age scale over the entire depth interval of the age scale refinement. The largest shifts (up to $1200 \mathrm{yr}$ ) can be observed in the period from 56-70 ka BP. In the older part, the changes in the age scale are lower than $400 \mathrm{yr}$. Due to new highresolution methane data, tie points between the TALDICE 


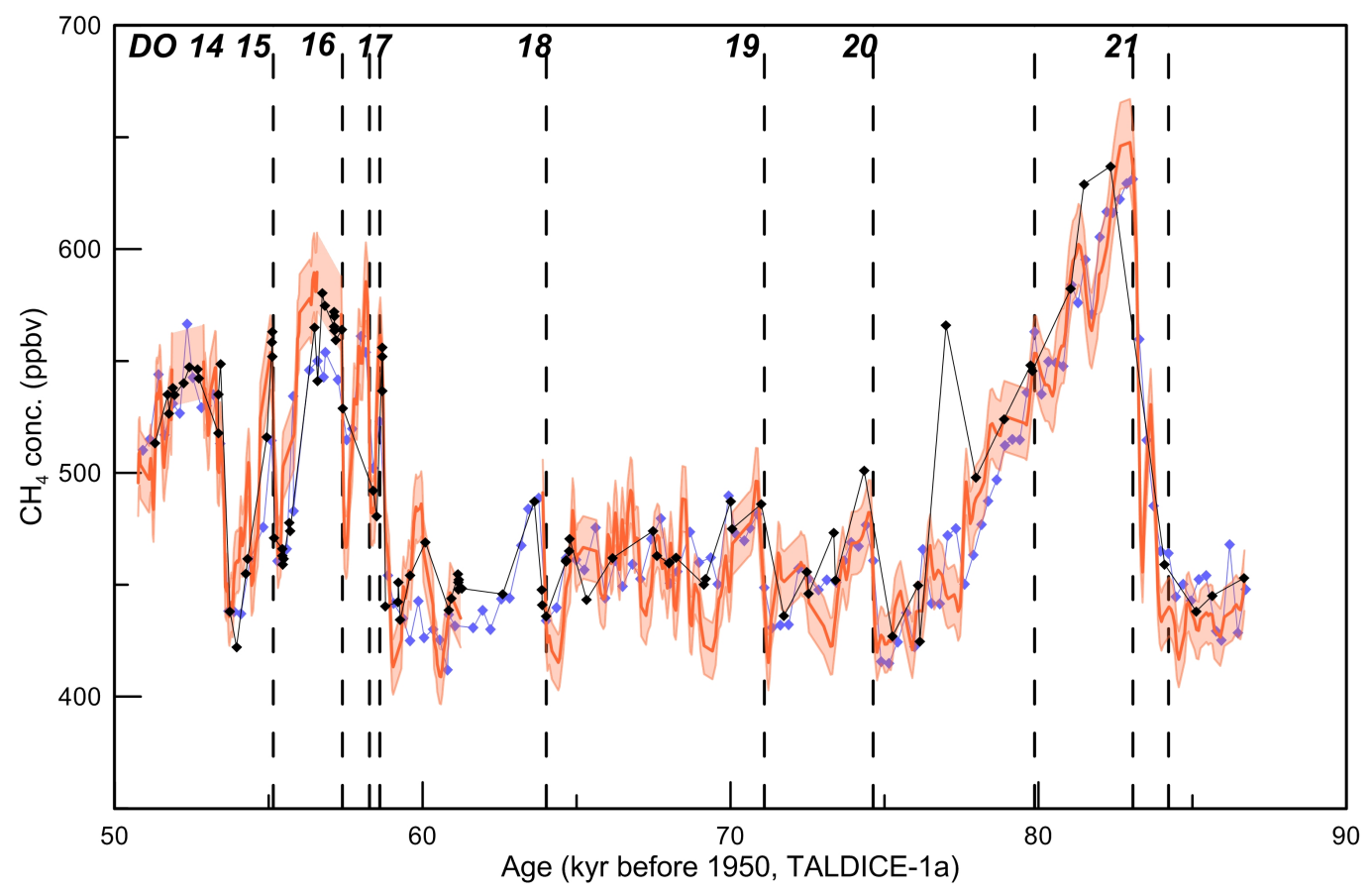

Fig. 2. The TALDICE $\mathrm{CH}_{4}$ records (black diamonds: discrete data (Buiron et al., 2011); orange line: new high-resolution data with the light orange band indicating a $\pm 3 \%$ error band) plotted on the refined TALDICE-1a age scale in comparison with the EDC $\mathrm{CH}_{4}$ record (blue diamonds) on the EDC3 age scale. Dashed lines indicate new tie points of the TALDICE-1a age scale; bold italic numbers indicate Dansgaard-Oeschger (DO) events.

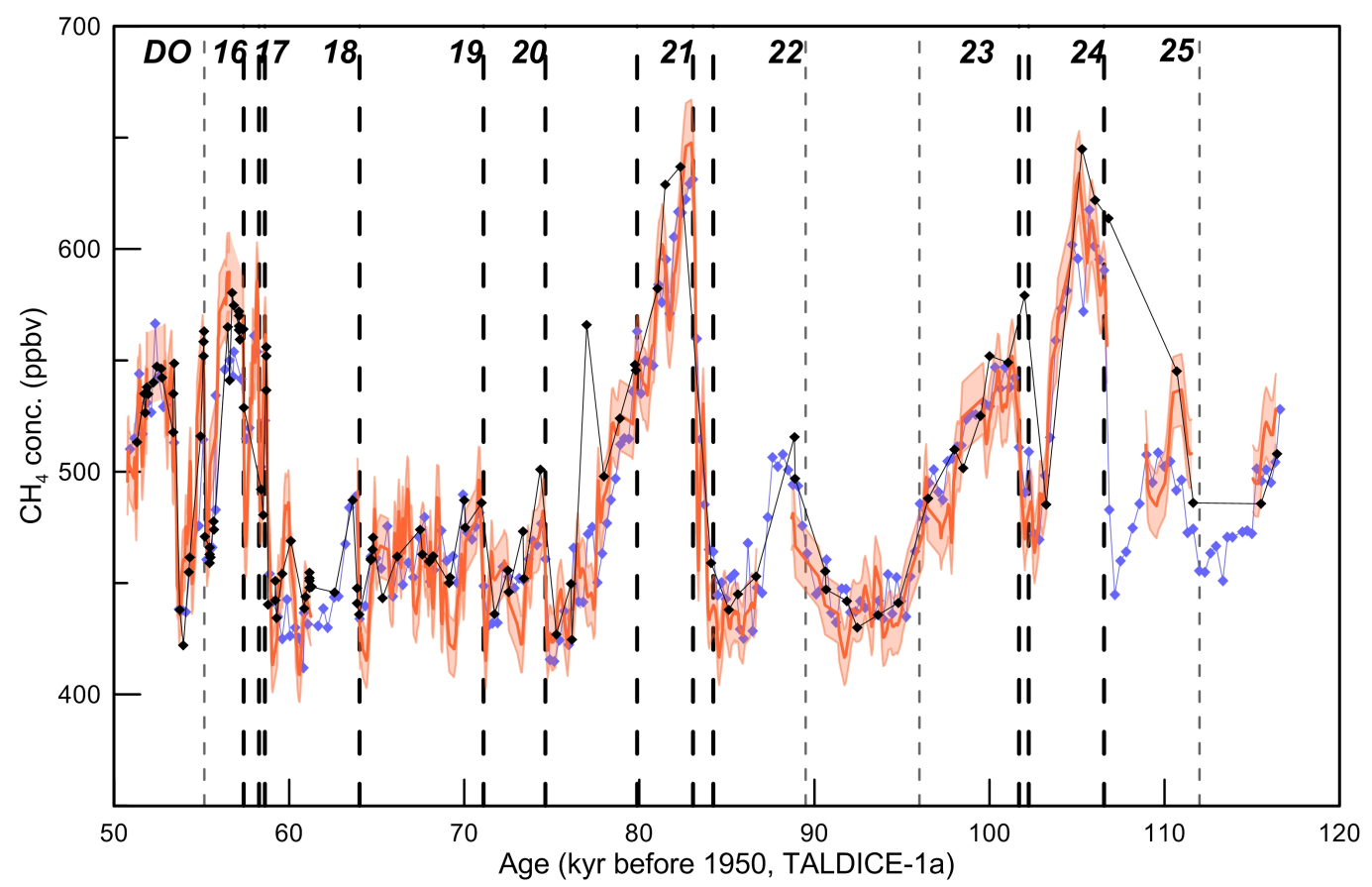

Fig. 3. The $\mathrm{CH}_{4}$ records (EDC: blue diamonds, discrete TALDICE data: black diamonds, new high resolution TALDICE data: orange line) on the whole interval from 55-112 ka BP where the TALDICE-1 age scale has been refined. Bold dashed lines indicate the new tie point; fine dashed lines indicate tie points adopted from the TALDICE-1 age scale; bold italic numbers indicate Dansgaard-Oeschger (DO) events. 


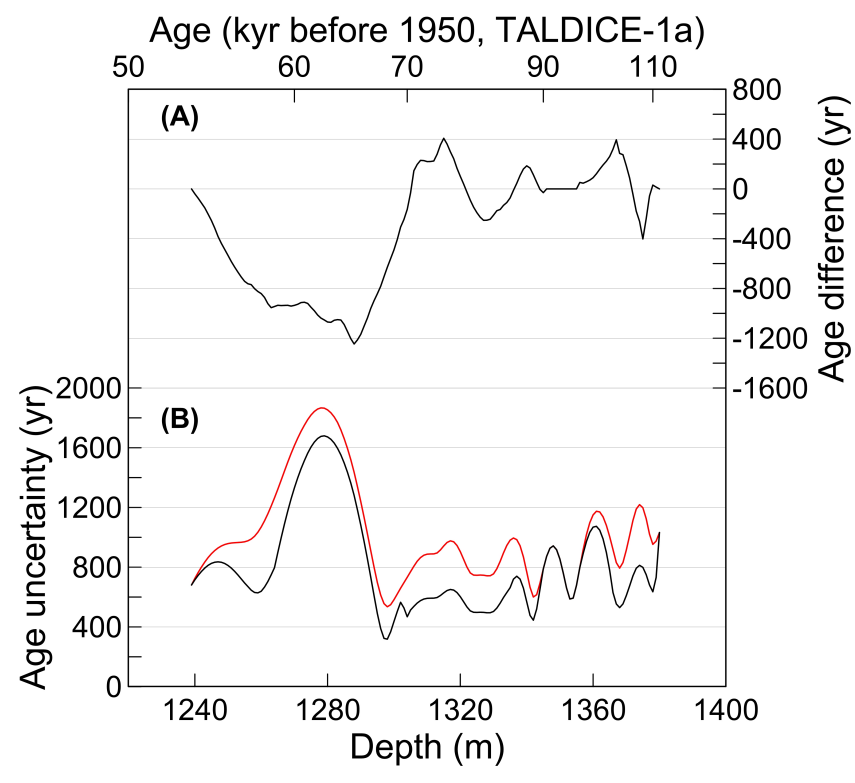

Fig. 4. (A) The ice age differences of the refined TALDICE-1a age scale compared to TALDICE-1 (the age difference is defined as TALDICE-1a age subtracted by the TALDICE-1 age at the respective depth). (B) Age uncertainties of the original TALDICE-1 ice age scale (red line), (Buiron et al., 2011) and the reduced uncertainties of the refined TALDICE-1a ice age scale (black line), respectively. The corresponding age (TALDICE-1a) is indicated on top.

and EDC $\mathrm{CH}_{4}$ records could be significantly constrained, yielding relative age uncertainties of 150-300 yr compared to $400-1500 \mathrm{yr}$ for the tie points in the TALDICE-1 age scale. The uncertainty of the ice age derived from synchronized gas records depends mainly on the $\Delta$ age uncertainties of both ice cores and of the uncertainty of the $\mathrm{CH}_{4}$ match. Thus, the better constrained gas tie points also reduce the uncertainty of the ice age scale, leading to relative age uncertainties between TALDICE and EDC of below $1100 \mathrm{yr}$ in the refined interval (except for the depth interval 1267-1290 m corresponding to 60-65 ka BP, where uncertainties reach up to $1500 \mathrm{yr}$ due to missing high-resolution $\mathrm{CH}_{4}$ data) compared to maximum uncertainties of $1900 \mathrm{yr}$ in the same interval with the TALDICE- 1 age scale. The uncertainties of the original TALDICE-1 ice age scale are compared to the new uncertainties of the TALDICE-1a ice age scale in the refined period in Fig. 4b. The new uncertainty is estimated by error propagation with unchanged $\Delta$ age uncertainties in EDC and TALDICE and the reduced new uncertainty from the gas tie points. While discussions of climate dynamics at sub-millennial time scales were possible back to the Marine Isotope Stage (MIS) 3.3 with the TALDICE-1 age scale, the refined age scale allows for such discussions back to MIS 5.3.

For the first time the precursor event of DO 21 has clearly been detected in methane in an Antarctic ice core (see Fig. 1). It has been measured in high-resolution and discussed before in the GISP2 ice core by Grachev et al. $(2007,2009)$ and, thus, has been independently verified by our measurements. Also the rapid variations of methane in the NGRIP ice core over DO 16 and 17 discussed in detail by Huber et al. (2006) have not been measured before in such resolution in Antarctica. The existence not only of fast transitions in methane during DO events in both Antarctic and Greenland ice cores, but now also the availability of precursor-like events in the methane records of both hemispheres allows for a discussion of the mechanisms at work at time scales of a few hundred years. However, the $\mathrm{EDC} \mathrm{CH}_{4}$ record does not show all the short events in methane due to limited depth resolution but also due to considerable smoothing of the gas records due to low accumulation and temperature. In contrast, the EDML $\mathrm{CH}_{4}$ record (Capron et al., 2010; EPICA, 2006; Schilt et al., 2010), which features good depth resolution in the discussed interval, shows the distinct variations over DO 1517, which allows for even more precise synchronization with the TALDICE $\mathrm{CH}_{4}$ record. Furthermore, no additional phasing uncertainty due to the bubble close-off characteristics is induced between TALDICE and EDML, since accumulation and temperature at both drilling sites are very similar. In Table 1 the corresponding tie points are also proposed for the EDML ice core based on synchronization with the new TALDICE $\mathrm{CH}_{4}$ record.

To demonstrate the impact of the refinement of the TALDICE- 1 age scale not only in gas records but also in the surrounding ice matrix, the $\mathrm{Ca}^{2+}$ concentration records of the TALDICE and EDC ice cores are compared on a selected interval from 54-80 ka BP. This represents an independent validation of our approach and the quality of the revised age scale.

Calcium in East Antarctic ice cores predominantly originates from terrestrial dust from southern South America during the last glacial period (Delmonte et al., 2008; Fischer et al., 2007). Therefore, changes in the flux of $\mathrm{Ca}^{2+}$ during this period should be synchronous across East Antarctica and can be used to synchronize ice core records from this region (Mulvaney et al., 2000). Thus, we compare the $\mathrm{Ca}^{2+}$ records to demonstrate the impact of the refined age scale on TALDICE. In Fig. $5 \mathrm{Ca}^{2+}$ concentrations from EDC and TALDICE are shown on the time interval from 54-80 ka BP on the EDC3 and the original TALDICE-1 age scales (A), and the refined TALDICE-1a age scale (B), respectively. In general, $\mathrm{Ca}^{2+}$ concentrations are approximately three times lower in TALDICE than the respective concentrations in the EDC ice core (note different scales of the ordinates in Figs. $4 \mathrm{a}$ and $\mathrm{b}$ ) over the discussed interval, primarily due to the higher accumulation rate at Talos Dome and secondly because of different transport times of Patagonian dust to Dome $\mathrm{C}$ and Talos Dome. The relative variations of the two $\mathrm{Ca}^{2+}$ records show high correlation as expected according to Mulvaney et al. (2000). However, the variations are substantially shifted in time when using the original TALDICE-1 age scale (Buiron et al., 2011) (see Fig. 5a). Especially between 60 and 


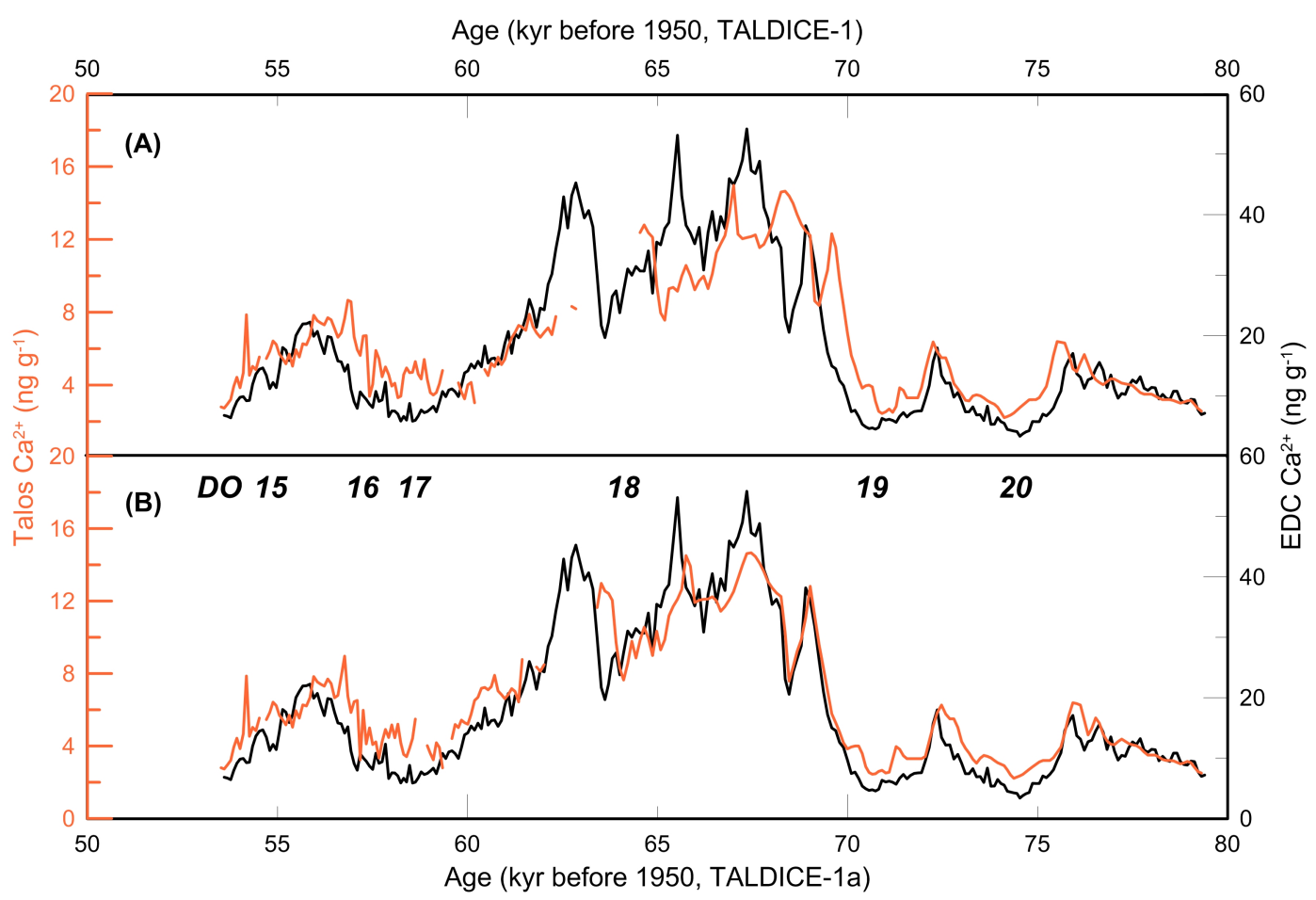

Fig. 5. The $\mathrm{Ca}^{2+}$ records from EDC (black line, Bigler et al., 2006) on the EDC3 age scale and from TALDICE (orange line, new data) on the original TALDICE-1 age scale (A) and the refined TALDICE-1a age scale (B), respectively, are compared on the interval from 54-80 $\mathrm{ka} \mathrm{BP}$. EDC data are shown as $1 \mathrm{~m}$ averages, TALDICE data as $50 \mathrm{~cm}$ averages. TALDICE data are interpolated to fit the EDC data at the respective ages. Bold italic numbers indicate Dansgaard-Oeschger (DO) events.

70 ka BP (covering DO 17-19) where highest $\mathrm{Ca}^{2+}$ concentrations are reached a temporal shift towards older ages in the order of $1000 \mathrm{yr}$ becomes apparent.

When using the refined TALDICE-1a age scale instead (Fig. 5b), the variations in the $\mathrm{Ca}^{2+}$ records are in phase within the error limits, confirming the consistency of the TALDICE-1a age scale and the EDC3 age scale in contrast to the TALDICE-1 age scale. Correlation of the TALDICE and $\mathrm{EDC} \mathrm{Ca}^{2+}$ records (246 data points each) in this interval is increased from $r^{2}=0.71$ using TALDICE- 1 to $r^{2}=0.89$ when the refined TALDICE-1a age scale is applied. Thus, not only in the interval where the largest corrections in the gas age scale have been applied (around DO 17, see Figs. 1 and 2), but also in other sections of the refined interval, a substantial improvement of the synchronization in both the gas and the ice age scale has been achieved by the use of the new high-resolution methane data. The first methane tie point of the refined age scale is at $55150 \mathrm{yr}$ BP (see Table 1) in the gas age, corresponding to an age of the surrounding ice of $56300 \mathrm{yr}$ BP. Thus, the ice age scale is readjusted only for ages older than 56,3 ka BP as can be seen in Fig. 5b. $\Delta$ age modeled by Buiron et al. (2011) is slightly overestimated in the age interval 55-67 ka BP, whereas for older ages it seems to fit well with the refined TALDICE-1a age scale.

\section{Conclusions}

The refined age scale TALDICE-1a presented in this work complements the TALDICE-1 age scale in the age interval from $55-112 \mathrm{ka}$ BP. This refinement is required for investigations of climate dynamics at sub-millennial time scales not only back to $50 \mathrm{ka} \mathrm{BP}$ as with the TALDICE-1 age scale but back to MIS 5.3 at $110 \mathrm{ka}$ BP. In particular, precise north-south synchronization is essential for the study of interhemispheric connections (Raisbeck et al., 2007; Stocker and Johnsen, 2003). The availability of such high-resolution $\mathrm{CH}_{4}$ data allows for more precise synchronizations with future ice cores which are also analyzed with on-line $\mathrm{CH}_{4}$ measurements. For the present purpose, absolute calibration of the $\mathrm{CFA}-\mathrm{CH}_{4}$ data, which remains a critical issue for on-line $\mathrm{CH}_{4}$ measurements, is not necessary. This greatly enhances the value of these data. Further improvements concerning the precision of the on-line measurements would then also allow for a better insight in the dynamics of the methane cycle on short time scales and at low concentration variations. With additional methane measurements to achieve higher resolution in the lower part of TALDICE (ages older than $130 \mathrm{ka} \mathrm{BP}$ ) and using $\mathrm{Ca}^{2+}$ for tie points in the ice matrix, the synchronization of TALDICE with EDC could further be improved in the future through the entire length of the 
ice core by using e.g. the inverse model by Lemieux-Dudon et al. (2010).

\section{Supplementary material related to this article is available online at: http://www.clim-past.net/7/1001/2011/ cp-7-1001-2011-supplement.zip.}

Acknowledgements. Financial support by the Swiss National Science Foundation and by the Prince Albert II of Monaco Foundation is acknowledged. The Talos Dome Ice core Project (TALDICE), a joint European programme, is funded by national contributions from Italy, France, Germany, Switzerland and the United Kingdom. Primary logistical support was provided by PNRA at Talos Dome. This is TALDICE publication no 13 .

Edited by: E. Brook

\section{References}

Bigler, M., Röthlisberger, R., Lambert, F., Stocker, T. F., and Wagenbach, D.: Aerosol deposited in East Antarctica over the last glacial cycle: Detailed apportionment of continental and sea-salt contributions, J. Geophys. Res., 111, D08205, doi:10.1029/2005JD006469, 2006.

Blunier, T. and Brook, E. J.: Timing of Millennial-Scale Climate Change in Antarctica and Greenland During the Last Glacial Period, Science, 291, 109-112, doi:10.1126/science.291.5501.109, 2001.

Blunier, T., Chappellaz, J., Schwander, J., Dallenbach, A., Stauffer, B., Stocker, T. F., Raynaud, D., Jouzel, J., Clausen, H. B., Hammer, C. U., and Johnsen, S. J.: Asynchrony of Antarctic and Greenland climate change during the last glacial period, Nature, 394, 739-743, doi:10.1038/29447, 1998.

Blunier, T., Spahni, R., Barnola, J. M., Chappellaz, J., Loulergue, L., and Schwander, J.: Synchronization of ice core records via atmospheric gases, Clim. Past, 3, 325-330, 2007, http://www.clim-past.net/3/325/2007/.

Brook, E. J., Harder, S., Severinghaus, J. P., Steig, E. J., and Sucher, C. M.: On the Origin and Timing of Rapid Changes in Atmospheric Methane During the Last Glacial Period, Global Biogeochem. Cy., 14, 559-572, doi:10.1029/1999GB001182, 2000.

Buiron, D., Chappellaz, J., Stenni, B., Frezzotti, M., Baumgartner, M., Capron, E., Landais, A., Lemieux-Dudon, B., MassonDelmotte, V., Montagnat, M., Parrenin, F., and Schilt, A.: TALDICE-1 age scale of the Talos Dome deep ice core, East Antarctica, Clim. Past, 7, 1-16, doi:10.5194/cp-7-1-2011, 2011.

Capron, E., Landais, A., Lemieux-Dudon, B., Schilt, A., MassonDelmotte, V., Buiron, D., Chappellaz, J., Dahl-Jensen, D., Johnsen, S., Leuenberger, M., Loulergue, L., and Oerter, H.: Synchronising EDML and NorthGRIP ice cores using $\delta^{18} \mathrm{O}$ of atmospheric oxygen $\left(\delta^{18} \mathrm{O}_{\mathrm{atm}}\right)$ and $\mathrm{CH}_{4}$ measurements over MIS5 (80-123 kyr), Quaternary Sci. Rev., 29, 222-234, doi:10.1016/j.quascirev.2009.07.014, 2010.

Chappellaz, J., Brook, E., Blunier, T., and Malaizé, B.: $\mathrm{CH}_{4}$ and $\delta^{18} \mathrm{O}$ of $\mathrm{O}_{2}$ records from Antarctic and Greenland ice: A clue for stratigraphic disturbance in the bottom part of the Greenland
Ice Core Project and the Greenland Ice Sheet Project 2 ice cores, J. Geophys. Res., 102, 26547-26557, 1997.

Delmonte, B., Andersson, P. S., Hansson, M., Schöberg, H., Petit, J. R., Basile-Doelsch, I., and Maggi, V.: Aeolian dust in East Antarctica (EPICA-Dome C and Vostok): Provenance during glacial ages over the last $800 \mathrm{kyr}$, Geophys. Res. Lett., 35, L07703, doi:10.1029/2008GL033382, 2008.

EPICA Community Members.: One-to-one coupling of glacial climate variability in Greenland and Antarctica, Nature, 444, 195198, 2006.

Fischer, H., Siggaard-Andersen, M.-L., Ruth, U., Röthlisberger, R., and Wolff, E.: Glacial/interglacial changes in mineral dust and sea-salt records in polar ice cores: Sources, transport, and deposition, Rev. Geophys., 45, RG1002, doi:10.1029/2005RG000192, 2007.

Fischer, H., Behrens, M., Bock, M., Richter, U., Schmitt, J., Loulergue, L., Chappellaz, J., Spahni, R., Blunier, T., Leuenberger, M., and Stocker, T. F.: Changing boreal methane sources and constant biomass burning during the last termination, Nature, 452, 864-867, 2008.

Goujon, C., Barnola, J. M., and Ritz, C.: Modeling the densification of polar firn including heat diffusion: Application to close-off characteristics and gas isotopic fractionation for Antarctica and Greenland sites, J. Geophys. Res., 108, 4792, doi:10.1029/2002JD003319, 2003.

Grachev, A. M., Brook, E. J., and Severinghaus, J. P.: Abrupt changes in atmospheric methane at the MIS 5b-5a transition, Geophys. Res. Lett., 34, L20703, doi:10.1029/2007GL029799, 2007.

Grachev, A. M., Brook, E. J., Severinghaus, J. P., and Pisias, N. G.: Relative timing and variability of atmospheric methane and GISP2 oxygen isotopes between 68 and $86 \mathrm{ka}$, Global Biogeochem. Cy., 23, GB2009, doi:10.1029/2008GB003330, 2009.

Huber, C., Leuenberger, M., Spahni, R., Flückiger, J., Schwander, J., Stocker, T. F., Johnsen, S., Landais, A., and Jouzel, J.: Isotope calibrated Greenland temperature record over Marine Isotope Stage 3 and its relation to $\mathrm{CH}_{4}$, Earth Planet. Sc. Lett., 243, 504-519, 2006.

Kaufmann, P. R., Federer, U., Hutterli, M. A., Bigler, M., Schüpbach, S., Ruth, U., Schmitt, J., and Stocker, T. F.: An Improved Continuous Flow Analysis System for High-Resolution Field Measurements on Ice Cores, Environ. Sci. Technol., 42, 8044-8050, doi:10.1021/es8007722, 2008.

Köhler, P., Knorr, G., Buiron, D., Lourantou, A., and Chappellaz, J.: Abrupt rise in atmospheric $\mathrm{CO}_{2}$ at the onset of the Bølling/Allerød: in-situ ice core data versus true atmospheric signals, Clim. Past, 7, 473-486, doi:10.5194/cp-7-473-2011, 2011.

Landais, A., Barnola, J. M., Kawamura, K., Caillon, N., Delmotte, M., Van Ommen, T., Dreyfus, G., Jouzel, J., Masson-Delmotte, V., Minster, B., Freitag, J., Leuenberger, M., Schwander, J., Huber, C., Etheridge, D., and Morgan, V.: Firn-air $\delta^{15} \mathrm{~N}$ in modern polar sites and glacial-interglacial ice: a model-data mismatch during glacial periods in Antarctica?, Quaternary Sci. Rev., 25, 49-62, 2006

Lelieveld, J., Crutzen, P. J., and Dentener, F. J.: Changing concentration, lifetime and climate forcing of atmospheric methane, Tellus B, 50, 128-150, doi:10.1034/j.1600-0889.1998.t01-100002.x, 1998. 
Lemieux-Dudon, B., Blayo, E., Petit, J.-R., Waelbroeck, C., Svensson, A., Ritz, C., Barnola, J.-M., Narcisi, B. M., and Parrenin, F.: Consistent dating for Antarctic and Greenland ice cores, Quaternary Sci. Rev., 29, 8-20, doi:10.1016/j.quascirev.2009.11.010, 2010.

Loulergue, L., Parrenin, F., Blunier, T., Barnola, J. M., Spahni, R., Schilt, A., Raisbeck, G., and Chappellaz, J.: New constraints on the gas age-ice age difference along the EPICA ice cores, 0-50 kyr, Clim. Past, 3, 527-540, 2007, http://www.clim-past.net/3/527/2007/.

Loulergue, L., Schilt, A., Spahni, R., Masson-Delmotte, V., Blunier, T., Lemieux, B., Barnola, J.-M., Raynaud, D., Stocker, T. F., and Chappellaz, J.: Orbital and millennial-scale features of atmospheric $\mathrm{CH}_{4}$ over the past 800,000 years, Nature, 453, 383386, 2008.

Mulvaney, R., Röthlisberger, R., Wolff, E. W., Sommer, S., Schwander, J., Hutterli, M. A., and Jouzel, J.: The transition from the Last Glacial Period in inland and near-coastal Antarctica, Geophys. Res. Lett., 27, 2673-2676, doi:10.1029/1999GL011254, 2000.

Parrenin, F., Barnola, J. M., Beer, J., Blunier, T., Castellano, E., Chappellaz, J., Dreyfus, G., Fischer, H., Fujita, S., Jouzel, J., Kawamura, K., Lemieux-Dudon, B., Loulergue, L., MassonDelmotte, V., Narcisi, B., Petit, J. R., Raisbeck, G., Raynaud, D., Ruth, U., Schwander, J., Severi, M., Spahni, R., Steffensen, J. P., Svensson, A., Udisti, R., Waelbroeck, C., and Wolff, E.: The EDC3 chronology for the EPICA Dome C ice core, Clim. Past, 3, 485-497, 2007, http://www.clim-past.net/3/485/2007/.

Raisbeck, G. M., Yiou, F., Jouzel, J., and Stocker, T. F.: Direct north-south synchronization of abrupt climate change record in ice cores using Beryllium 10, Clim. Past, 3, 541-547, 2007, http://www.clim-past.net/3/541/2007/.
Röthlisberger, R., Bigler, M., Hutterli, M., Sommer, S., Stauffer, B., Junghans, H. G., and Wagenbach, D.: Technique for Continuous High-Resolution Analysis of Trace Substances in Firn and Ice Cores, Environ. Sci. Technol., 34, 338-342, doi:10.1021/es9907055, 2000.

Schilt, A., Baumgartner, M., Blunier, T., Schwander, J., Spahni, R., Fischer, H., and Stocker, T. F.: Glacial-interglacial and millennial-scale variations in the atmospheric nitrous oxide concentration during the last 800,000 years , Quaternary Sci. Rev., 29, 182-192, doi:10.1016/j.quascirev.2009.03.011, 2010.

Schüpbach, S., Federer, U., Kaufmann, P. R., Hutterli, M. A., Buiron, D., Blunier, T., Fischer, H., and Stocker, T. F.: A New Method for High-Resolution Methane Measurements on Polar Ice Cores Using Continuous Flow Analysis, Environ. Sci. Technol., 43, 5371-5376, doi:10.1021/es9003137, 2009.

Schwander, J., Barnola, J. M., Andrié, C., Leuenberger, M., Ludin, A., Raynaud, D., and Stauffer, B.: The Age of the Air in the Firn and the Ice at Summit, Greenland, J. Geophys. Res., 98, 28312838, 1993.

Spahni, R., Schwander, J., Flückiger, J., Stauffer, B., Chappellaz, J., and Raynaud, D.: The attenuation of fast atmospheric $\mathrm{CH}_{4}$ variations recorded in polar ice cores, Geophys. Res. Lett., 30, 1571, doi:10.1029/2003GL017093, 2003.

Spahni, R., Chappellaz, J., Stocker, T. F., Loulergue, L., Hausammann, G., Kawamura, K., Fluckiger, J., Schwander, J., Raynaud, D., Masson-Delmotte, V., and Jouzel, J.: Atmospheric Methane and Nitrous Oxide of the Late Pleistocene from Antarctic Ice Cores, Science, 310, 1317-1321, doi:10.1126/science.1120132, 2005.

Stocker, T. F. and Johnsen, S. J.: A minimum thermodynamic model for the bipolar seesaw, Paleoceanography, 18, 1087, doi:10.1029/2003PA000920, 2003. 